\title{
For Members Only
}

AUGUSTAN REPRINTS. The editorial board of the Augustan Reprint Society continues to invite proposals to reprint worthy and rare titles from ca. 1660-1790. In recent years, most proposals have been for plays and dramatic criticism. To maintain balance, the editors would be especially interested in other genres: e.g., history, history of ideas, philosophy, the arts. The primary emphasis of this Society continues to be literary, but titles of other kinds are welcome if they increase the understanding of literary works. The normal maximum length of pages reprinted in an issue is 45 , exclusive of introduction. Shorter pieces are especially welcome. Inquiries about past reprints and membership in the Society can be obtained from its corresponding secretary: Mrs. Edna C. Davis, William Andrews Clark Memorial Library, 2205 West Adams Blvd., Los Angeles, California 90018. Seventeenth-century titles are normally first reviewed by Earl Miner (UCLA); 18th century by M. E. Novak (UCLA).

FIFTY. Congratulations to the fourteen members who have achieved their fiftieth continuous year in the association: William E. Alderman (Miami, Ohio), John B. DeForest (Vermont), Louise Dudley (Stephens Coll.), John DeLancey Ferguson (Brooklyn Coll.), George Franklin French (Andover), Garland Greever (Univ. of So. Calif.), William Haller (Folger), Harry Worthington Hastings (New York SUC, Albany), Richard Foster Jones (Stanford), Paul Kaufman (Washington), Robert Porter Keep (Miss Porter's School, Farmington, Conn.), Edward Colby Knowlton (Wisconsin SC, LaCrosse), Julian Ira Lindsay (Vermont), Harry Lee Ridenour (Baldwin-Wallace). Like golden weddings, fiftieth anniversaries are more than most of us can survive, and the more to be cherished therefore. These figures are annually compiled by our own Ruth Olson, who is this year celebrating her thirty-sixth year with the headquarters office.

SHAKESPEARE QUADRICENTENNIAL. The Pacific Northwest Renaissance Conference sponsored a conference 6.7 March which is to result in Pacific Coast Studies in Shakespeare, a collection of some twenty essays to be published by the Univ. of Oregon Press, general editor Waldo F. McNeir. The Shakespeare Newsletter of April is a 50-page commemorative issue containing articles, a list of paperbacks in print, Shakespeare dissertations for the last 40 years, histories of Shakespeare festivals, and much else.

LIST OF DEPARTMENTAL CHAIRMEN. In April the 1963 entries, clipped and pasted to a return postcard, are sent to the registrar of each college and university for correction. In order to avoid confusion, registrars are asked for names of chairmen of $d e$ partments only-not chairmen of programs. If the entry for your institution does not show correct organization, we would appreciate a brief and authoritative correction.
VIGNETTE LXXXI. Our new Council member Victor Erlich (Yale) was born in Petrograd on 22 November 1914. His father, a leader of the Polish-Jewish Socialist Bund, was a member of the Petrograd Soviet in 1917. He opposed the Bolshevik Revolution, however, and as a result in 1918 had to move back to his native Poland. Victor Erlich grew up in Warsaw, studying Slavic philology at the Free Polish University there and receiving his M.A. in 1937. He worked for a while as a free-lance journalist and as assistant editor for a magazine called New Life. The outbreak of the war with Germany changed everything. His father was arrested by the Russians and executed in 1941. Victor Erlich himself had many narrow escapes; he managed to get out of Warsaw just before it fell to the Nazis, and to reach Lithuania where he married his present wife. Together they traveled across Russia and Siberia, and early in 1941, before the outbreak of war between Russia and Germany, reached Vladivostok. They went to Japan and then to Canada, shortly before Pearl Harbor, spending a year in Montreal while waiting for U.S. immigration visas. In New York Erlich went to work for Yiddish Encyclopedia but was almost at once drafted by the U. S. Army. During the last offensive into Germany, early in 1945 , he was severely wounded by a sniper. He received a medical discharge and was awarded the Purple Heart. He resumed his studies at Columbia University, working under Roman Jakobson and Ernest J. Simmons and receiving his Ph.D. in 1951 upon completion of a brilliant thesis on the Russian Formalist movement. As early as 1948 he had taken up teaching at the University of Washington. Here he rose quickly to a full Professorship, Chairmanship of the Division of Slavic Languages and Literatures, and eventually Assistant Directorship of the Far Eastern and Russian Institute. He was a Ford Fellow at Harvard University in 1953-54 and a Fulbright Professor at the University of Leiden in 1957-58. He has held Guggenheim and ACLS fellowships. In 1962 he came to Yale as Visiting Professor and in 1963 was appointed Bensinger Professor of Russian Literature. Russian and Polish literature of the nineteenth and twentieth centuries are his principal areas, but he has an extraordinary knowledge of other literatures, of Soviet culture and society, of literary theory and aesthetics. His major publications are Russian Formalism: History-Doctrine (The Hague, 1955) and essays on Soviet literary criticism, on Gogol, Kafka, Pasternak, Mayakovsky, and others, and on the use of the monologue in narrative fiction. A collection of his essays on the image of the poet in Russian and Polish literature was published in April 1964 by the Johns Hopkins Press under the title The Double Image. Erlich is emphatic in saying that he has no hobbies, but he has at least one: that is, conversation, stories and anecdotes, discussion of persons and ideas. He is a highly sociable person, articulate in many languages, outgoing, communicative, an enthusiastic teacher and a devoted scholar, with a gift for friendship. 